\title{
Functional anatomy of the spermatheca and its duct in the seed bug Lygaeus simulans (Heteroptera: Lygaeidae)
}

\author{
RoBERT GSCHWENTNER and ANDREAS TADLER \\ Institute of Zoology and Limnology, University of Innsbruck, Technikerstrasse 25, A-6020 Innsbruck, Austria; \\ e-mail: robert.gschwentner@uibk.ac.at
}

Key words. Lygaeidae, Lygaeus simulans, insemination, genitalia, spermatheca, spermathecal muscle, spermathecal duct

\begin{abstract}
Female genitalia of lygaeid bugs are characterized by a tube-shaped ductus receptaculi (spermathecal duct) connecting the bursa copulatrix with the highly coiled receptaculum seminis (spermatheca). In this study the morphology and functional anatomy of these structures in Lygaeus simulans were examined by light-, fluorescence- and electron microscopy. In addition, copulating animals were freeze fixed and their interconnected genital structures observed using light microscopy. The ductus receptaculi is separated from the receptaculum seminis by a complicated valve. The valve is nearly surrounded by the spermathecal muscle, which controls its opening. The ductus receptaculi leads into the proximal convoluted tube of the receptaculum seminis. Both the ductus receptaculi and the convoluted tube are composed of a single layer of epithelial cells lined by a thick electron dense apical cuticle. The distal part of the receptaculum seminis is a brownish, irregularly coiled, blind ending canal made of small epithelial cells covered with cuticle. Big glands are present in the epidermal layer. The cuticle of this distal part is much thinner and features concentric lamellae. The lumen of the receptaculum seminis cannot be expanded. For transfering sperm into the receptaculum the male aedeagus is equipped with a long, tube-like, sclerotized appendix (processus gonopori), which enlarges the ductus receptaculi considerably during copulation. For successful insemination the tip of the processus gonopori has to pass the valve. The convoluted tube, the valve and the surrounding spermathecal muscle may enable females to control insemination and egg fertilization.
\end{abstract}

\section{INTRODUCTION}

There are few studies on the morphology of the genital organs of lygaeid bugs (Ekblom, 1926; Ludwig, 1926; Bonhag \& Wick, 1953; Pendergrast, 1957; Kahlov, 1962; Micholitsch, 1997). These investigations were mainly done by light-microscopy. Female Lygaeidae show a great variety in the length of their ductus receptaculi and a confusing diversity in the form of their receptaculum seminis (Pendergrast, 1957). Spermathecal muscles are common. Lygaeus simulans Deckert, 1985 is characterized by a long ductus receptaculi, a distinct receptaculum seminis and spermathecal musculature surrounding a part of the ductus and the receptaculum. The valve at the distal end of the ductus was first observed by Micholitsch (1997).

Previous observations showed that about one third of the copulations in $L$. simulans do not result in insemination (Micholitsch, 1997; Tadler et al., 1999). In addition, Tadler (1999) showed that males with processus gonopori of an intermediate length tended to have a higher insemination success than males with an extremely long processus. This selection is predicted by the female choice hypothesis of genitalia (Eberhard, 1985) and points to specialized control structures in female genitalia. In $L$. simulans the most probable location for such an insemination is the area around the valve, since the tip of the male processus has to penetrate this valve for successful insemination. In this study the morphological and histological characteristics of the ductus receptaculi, the receptaculum seminis and the valve of $L$. simulans are described and their possible function in female control over insemination discussed.

\section{MATERIAL AND METHODS}

Specimens of Lygaeus simulans Deckert, 1985 were collected in 1996-1998 near Hundsheim in Lower Austria. Using a dissecting microscope this species is easily discriminated from the similar L. equestris (L.) by the characters given in Deckert (1985). Females and males of $L$. simulans were kept separately at room temperature in Petri dishes containing peeled sunflower seed and distilled water. To observe copulation, 13 females and males were placed in pairs in Petri dishes. After $40 \mathrm{~min}$ of copulation pairs were fixed in $75 \%$ ethanol at $-20^{\circ} \mathrm{C}$ for 2 weeks. Interconnected copulatory organs were dissected from this material.

For semi-thin sections and scanning electron microscopy (SEM), female genitalia were fixed in Dubosq-Brasil (Romeis, 1968 ) for $24 \mathrm{~h}$, dehydrated in ethanol and embedded in epoxy resin (ERL 4206, Spurr, 1969), with propylenoxide as the intermediate medium. After reemoving genital organs for SEM, the resin was removed in ethanol and $\mathrm{NaOH}$ (Böck, 1984). The organs were dehydrated in a graded methanol series and criticalpoint dried. Samples were coated with gold and observed in a Zeiss DSM 950 scanning electron microscope at $15 \mathrm{kV}$. Semithin sections $(2 \mu \mathrm{m})$ were stained with methylene blue-azur II at $80^{\circ} \mathrm{C}$ (Richardson et al., 1960).

For transmission electron microscopy, a modified Bouinsfluid (Stefanini et al., 1967) was injected into the abdomens of animals $30 \mathrm{~min}$ prior to dissection. The organs were immersed in $2.5 \%$ glutaraldehyde in $0.001 \mathrm{M}$ phosphate buffer (PBS) and washed in $0.001 \mathrm{M}$ sodium-cacodylate buffer. They were postfixed in $2 \%$ osmium tetroxide with $2.5 \% \mathrm{~K}$-ferrocyanide in $0.001 \mathrm{M}$ sodium-cacodylate buffer, dehydrated in a graded acetone series and embedded in epoxy resin (ERL 4206), using propylenoxide as the intermediate medium. Ultrathin sections (75 


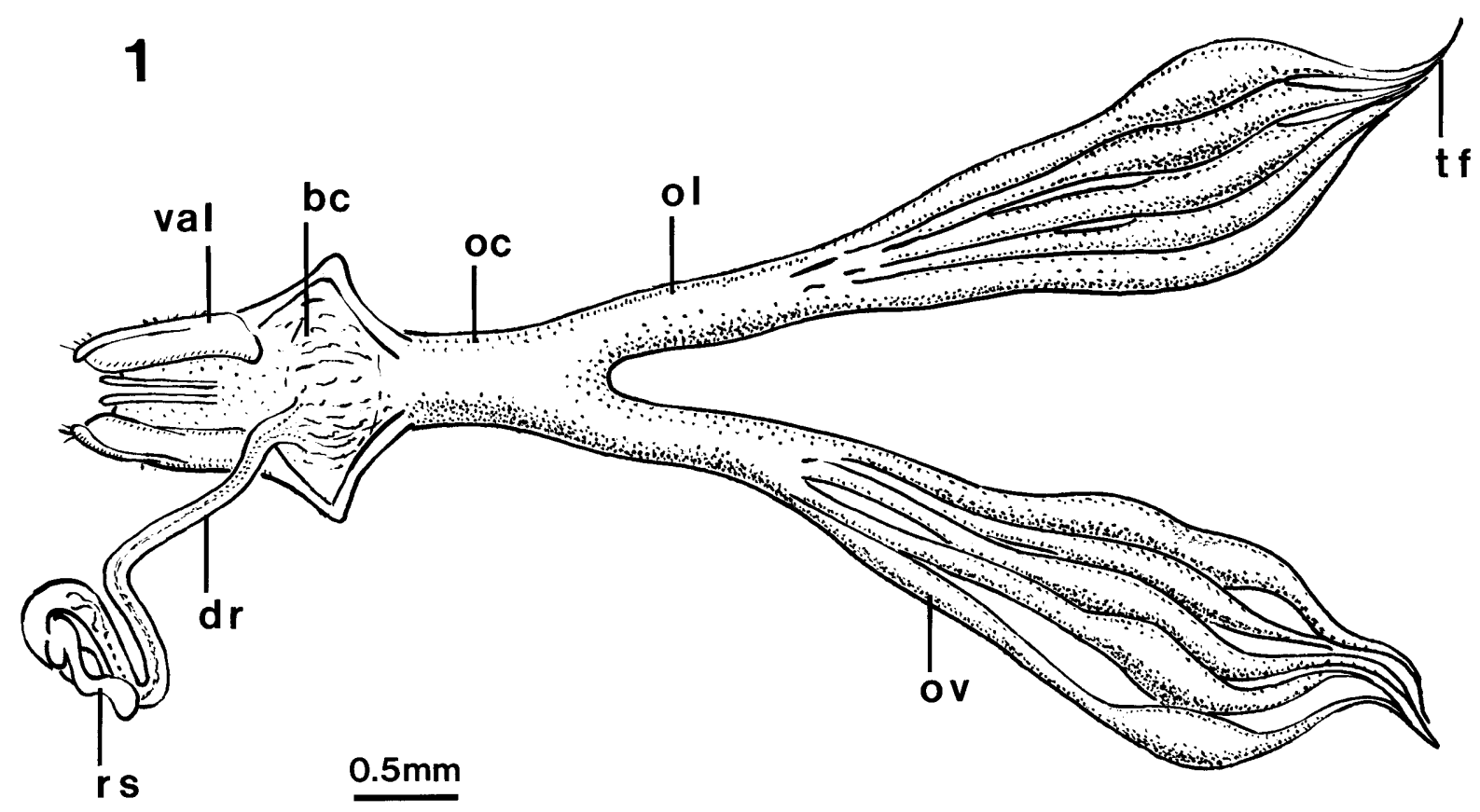

Fig. 1. Female genital organs of L. simulans. bc - bursa copulatrix; $\mathrm{dr}$ - ductus receptaculi; oc - oviductus communis; ol - oviductus lateralis; ov - ovaries; rs - receptaculum seminis; tf - terminal filament; val - valvula.

nm) were cut on a Reichert Ultracut E microtome, double stained with uranyl acetate and lead citrate, and observed using a Zeiss EM 902 electron microscope at $80 \mathrm{kV}$.

Immuncytochemical methods and a fluorescence technique (Rieger et al., 1994) were used to locate F-actin. Organs were fixed in modified Bouins, washed in 0.1 M PBS ( $\mathrm{pH} 7.4)$ and treated in $1 \%(\mathrm{~W}: \mathrm{v})$ bovine serum albumin plus $0.1 \%(\mathrm{v}: \mathrm{v})$ Triton X-100 in $0.1 \mathrm{M}$ PBS for $1 \mathrm{~h}$. Phalloidin (phalloidin Bodipy-558/568, Molecular probes, dilution $1: 30$ ) incubation was carried out for one hour at room temperature in 0.1 M PBS containing $0.1 \%$ Triton $\mathrm{X}-100$. Organs were washed in PBS $(3 \times$ $15 \mathrm{~min}$ ), mounted in Vectashield (Vectashield Laboratories) and observed under a Reichert Polyvar epifluorescence microscope.

A CFP Stimulator model 8084 was used to stimulate the spermathecal musculature in situ in the animal, after exposure by dissection. Electrical pulses ranged from 5-25 Volts and 1-50 Hertz. Leg-muscles of these animals were used as a control.

\section{RESULTS}

\section{Anatomy of female genitalia}

The internal structure of the female genitalia of Lygaeus simulans conform with the general model of the genitalia of female insects (Snodgrass, 1935). The ovarioles of the paired ovaries end distally in a terminal filament (Fig. 1). Proximally, the ovarioles open into the oviductus laterales. These merge in an oviductus communis, which in turn opens into the bursa copulatrix (genital chamber; Fig. 1). The vaginal orifice is formed by two membrane-connected valvulae. The ductus receptaculi (spermathecal duct) emerges from the dorsum of the bursa copulatrix and distally forms a loop of one and a half turns before entering the receptaculum seminis (Fig. 1). In the resting state the ductus is about $1.9 \mathrm{~mm}$ long, during copulation it can be up to $6 \mathrm{~mm}$ long. There is a valve at the distal end of the ductus receptaculi (Figs 2-3). The receptaculum seminis lies dorsal to the bursa copulatrix and consists of two parts: (i) proximally a convoluted tube, which is up to $0.45 \mathrm{~mm}$ long and (ii) distally an irregular coiled, blind ending brownish canal approximately $2.9 \mathrm{~mm}$ in length (Fig. 2). The convoluted tube lacks the typical brown colour of the distal part of the receptaculum seminis (Fig. 2). The entire receptaculum is enveloped by fat tissue. The inner surface of the distal part of the receptaculum seminis and of the ductus receptaculi is lined with different cuticular layers (Figs 4-6). The valve and the convoluted tube are partly surrounded by a thick layer of spermathecal muscle fibres.

\section{Ductus receptaculi (spermathecal duct)}

The wall of the ductus receptaculi consists of a single layer of epithelial cells resting on a basement membrane and covered with an apical cuticle (Fig. 7). The large nuclei of these cells occur at the same distance from the basal matrix, and their diameter is approximately $4.5 \mu \mathrm{m}$ (Figs 4-7). The well developed heterochromatin is positioned mainly in the outer region of the nuclei and a prominent nucleolus is obvious. Endoplasmic reticulum, Golgi apparatus and numerous mitochondria are present in the cytoplasm. Epithelial cells possess an extensive microvilliar zone beneath the cuticle (Fig. 7). The lateral cell membranes are highly folded and joined to the membranes of neighbouring cells by long septate junctions and by apical zonulae adhaerentes.

The elaborate procuticle of the ductus (about 30-35 $\mu \mathrm{m}$ thick) consists of an inner lamellar endocuticle and an outer homogenous exocuticle (Fig. 4). In cross section the endocuticle shows indentations in the area of the epithelial cells (Figs 4-7); the whole cuticle is radially orientated (Fig. 4).

The procuticle is covered by a thin epicuticle (about 1 $\mu \mathrm{m}$ thick), which encloses the lumen of the canal. The 


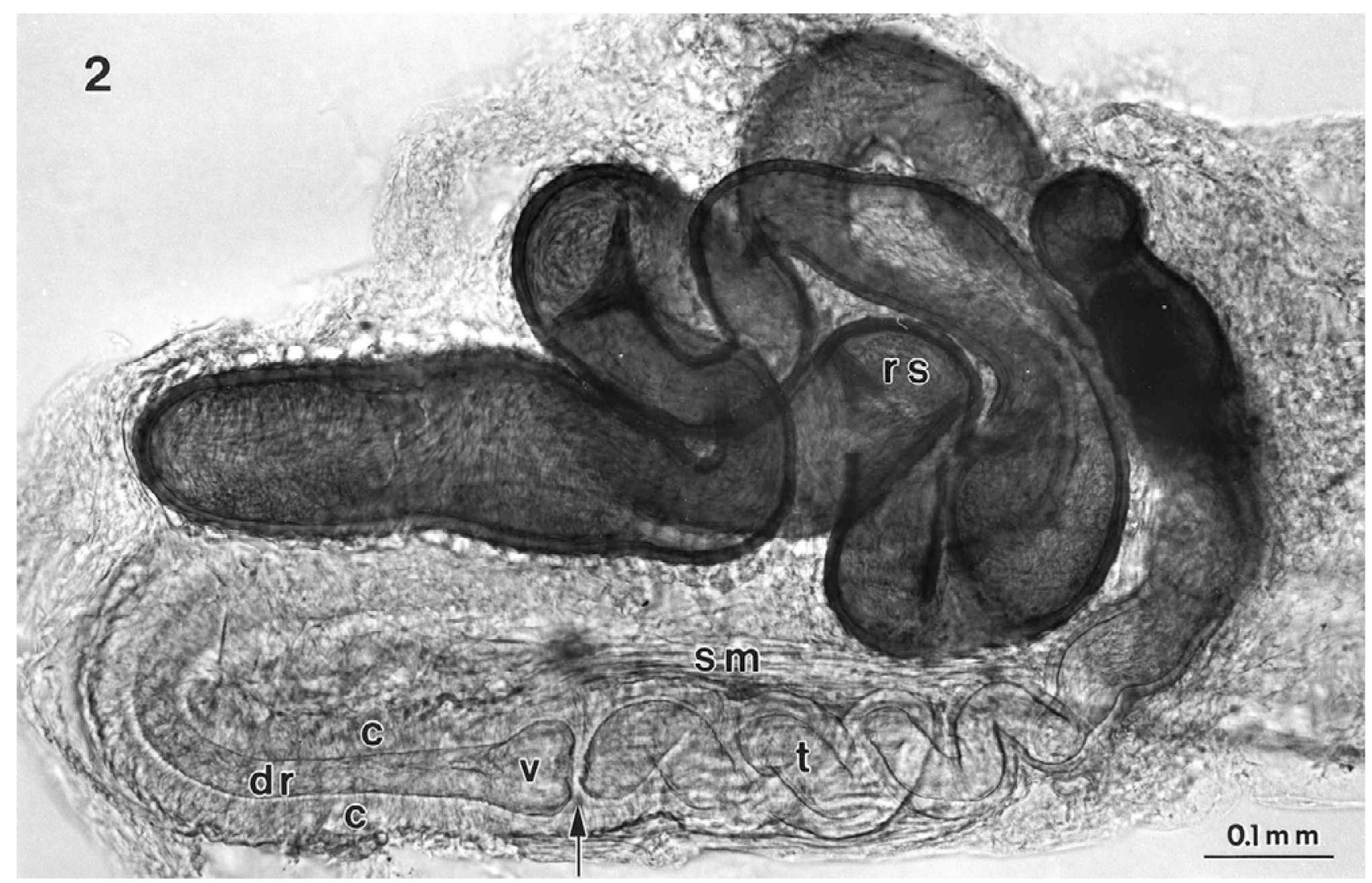

Fig. 2. Normarsky interference contrast photograph of the receptaculum seminis (rs), the convoluted tube (t) and the ductus receptaculi (dr). Note thick cuticule (c), valve structure (v) of ductus receptaculi and the cuticular wall separating the ductus from the receptaculum (arrow). The spermathecal muscle $(\mathrm{sm})$ partly surrounds valve and convoluted tube.

diameter of the lumen $(20-27 \mu \mathrm{m})$ is less than the thickness of the cuticle (Fig. 4). Spindle-shaped pore canals (about $1 \mu \mathrm{m}$ long and $0.1 \mu \mathrm{m}$ wide) occur randomly in the cuticle (Fig. 7). The valve at the distal end of the ductus forms an atrium and is separated from the receptaculum by a cuticular wall (Figs $2-5$ ). On this wall there are cuticular protrusions (Fig. 5), which are 5-8 $\mu \mathrm{m}$ long and extend into the ductus as well as into the convoluted tube of the receptaculum.

\section{Receptaculum seminis (spermatheca)}

The proximal part of the receptaculum seminis is a convoluted tube in the shape of a corkscrew. The epithelial cells, the nature of the cuticle and the colouration of this tube resemble that of the ductus receptaculi, but one function of the tube is to store sperm, which makes it a part of the receptaculum. The distal, irregularly coiled canal of the receptaculum seminis consists of small epithelial cells and large epidermal gland cells (Figs 6-8). Epithelial cells possess large nuclei (about 4-6 $\mu \mathrm{m}$ in diameter) with well developed heterochromatin and an indistinct microvilliar zone (Fig. 8). The epidermal glands are positioned beneath the epithelial cells and do not secrete cuticle (Fig. 8 ). The entire cuticular wall is about $10-15 \mu \mathrm{m}$ thick, the diameter of the lumen ranges from 50 to $100 \mu \mathrm{m}$ (Figs $2-6$ ). The concentric lamellae in the cuticule are obvious (Fig. 6-8). No indentations could be observed along the lamellae (Fig. 8).

\section{Spermathecal muscle}

Phalloidin labelling was mainly used to establish the overall pattern of organization of the spermathecal musculature, it was not suitable for studying the organization of the actin cytoskeleton. The convoluted tube of the receptaculum seminis and the distal part of the ductus receptaculi, including the valve, are nearly surrounded by spermathecal muscle (Figs 2-3). The muscle fibres are attached proximally to the ductus immediately in front of the valve (Fig. 3), and distally along the convoluted tube. The muscle fibres are connected with each other and the base of modified epithelial cells by desmosoms (Fig. 7). Microtubules are present in this region of epithelial cells and connect the spermathecal muscle with the cuticle, sometimes via a special swelling (Fig. 7). Electrical stimulation of the longitudinal spermathecal muscle never induced a contraction, although similar treatment of the skeletal muscles of the leg of the same animal induced contraction.

\section{Copulation}

The male processus gonopori is a 6.4 to $7.2 \mathrm{~mm}$ long sclerotized, tube-shaped appendix of the aedeagus. During copulation, the male inserts its processus, with complicated manoeuvers, into the bursa copulatrix and subsequently into the ductus receptaculi of the female. The diameter of the processus ranges from 75 to $85 \mu \mathrm{m}$, which is two to three times larger than the diameter of the lumen of the ductus. Thus the inserted processus expands 


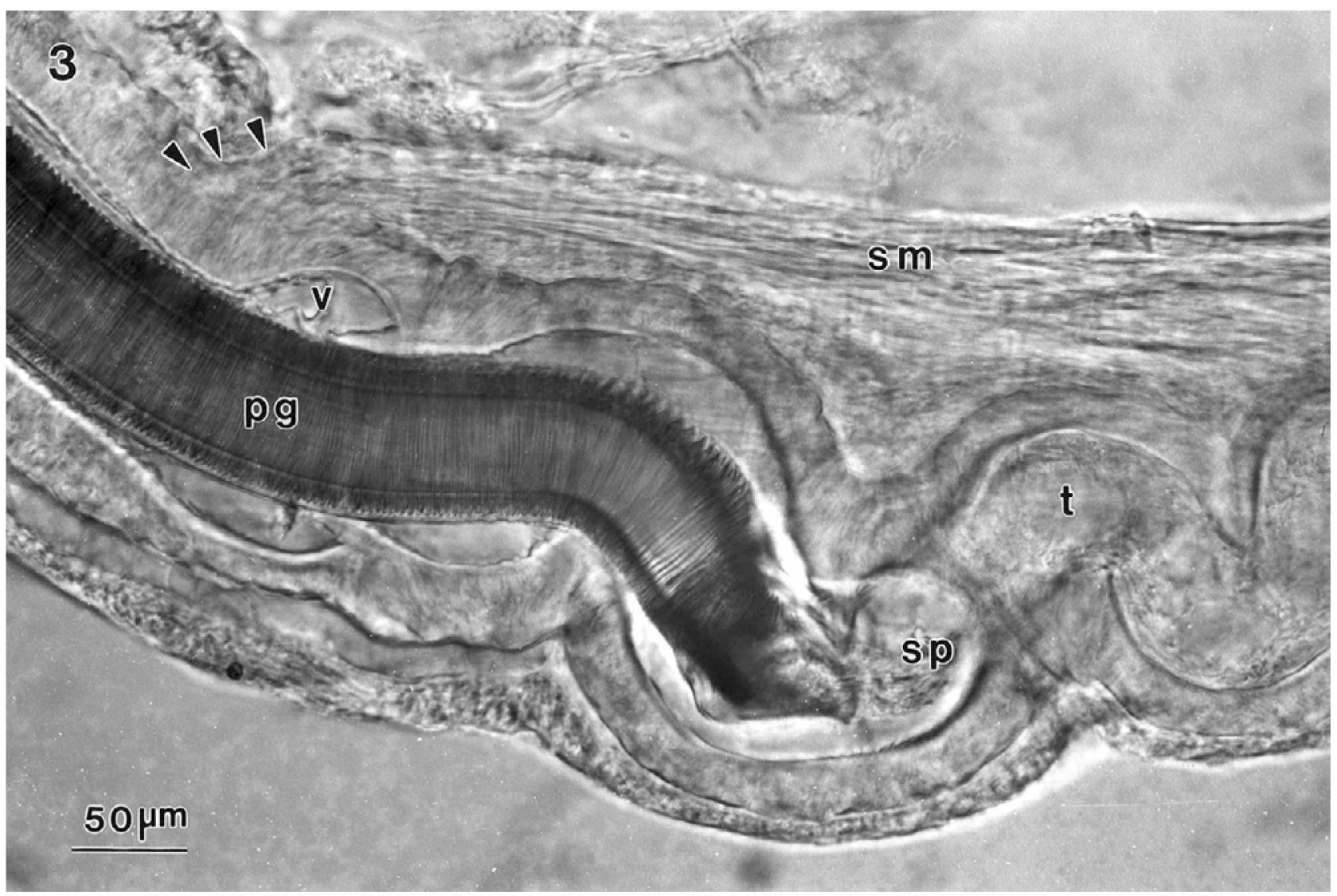

Fig. 3. Normarsky interference contrast photograph of valve (v) of ductus receptaculi and convoluted tube (t) of receptaculum seminis, with inserted male processus gonopori (pg). Note ejaculated sperm (sp) in convoluted tube and attachment sites (arrowheads) of spermathecal muscle (sm).

the ductus considerably. In order to deposit sperm into the receptaculum seminis the tip of the processus gonopori has to pass through the valve at the distal end of the ductus (Fig. 3). Only in five of the 13 pairs of $L$. simulans, which were freeze fixed after $40 \mathrm{~min}$ of copulation, had the valve been penetrated and sperm transferred (Fig. 3). In these pairs, the processus gonopori never reached further than half way along the length of the convoluted tube of the receptaculum seminis, even in pairs that copulated for more than $40 \mathrm{~min}$. In the remaining eight pairs the processus gonopori had reached the ductus receptaculi but not the valve and no sperm had been transferred.

\section{DISCUSSION}

The female copulatory organ of Lygaeus simulans features a long ductus receptaculi, an irregularly coiled receptaculum seminis and complicated associated structures: the valve, the convoluted tube and the spermathecal muscle. The valve in $L$. simulans was first discribed by Micholitsch (1997).

The ductus receptaculi of $L$. simulans has a thick lamellar endocuticle and a homogenous exocuticle, both with spindle shaped pore canals and indentations. Epithelial cells have greatly folded apical membranes and distinct microvilliar zones. The structure of the cuticle resembles that of the ductus receptaculi of Aedes aegypti (L.) (Culicidae, Clements \& Potter, 1967) and the distal part of the ductus receptaculi of Sitophilus granarius (L.) (Curculionidae, Tombes \& Roppel, 1972). Similar shaped cuticular pore canals occur in Oncopeltus fasciatus (Dallas) (Lygaeidae, Smith, 1968). The ductus receptaculi of L. simulans can be enlarged greatly.

The cuticle of the distal part of the receptaculum seminis of $L$. simulans is thinner than that of the ductus and is made up of concentric layers without indentations, and the epithelial cells are significant smaller. The large epidermal glands correspond to those of class 3 according to Noirot \& Quennedey (1974), although no cuticular duct is visible in our sections. This cellular configuration is present in the receptaculum seminis of several other insects, e.g. from $O$. fasciatus (Lygaeidae) Bonhag \& Wick (1953), A. aegypti (Culicidae) Clements \& Potter (1967), S. granarius (Curculionidae) Tombes \& Roppel (1972), Crematogaster opuntiae Lund (Formicidae) Wheeler \& Krutzsch (1994) and Frankliniella occidentalis (Pergande) (Thripidae) Dallai et al. (1996). The cuticle of the receptaculum of $L$. simulans is comparable to that of C. opuntiae (Wheeler \& Krutzsch, 1994), which is rigid and not very elastic.

The valve at the distal end of the ductus receptaculi of $L$. simulans separates the ductus from the receptaculum. Ludwig's (1926) description of $L$. equestris does not mention a valve. He assumed that contraction of the spermathecal musculature closes the convoluted tube (=Verschlussstïck), which is positioned before the recep- 

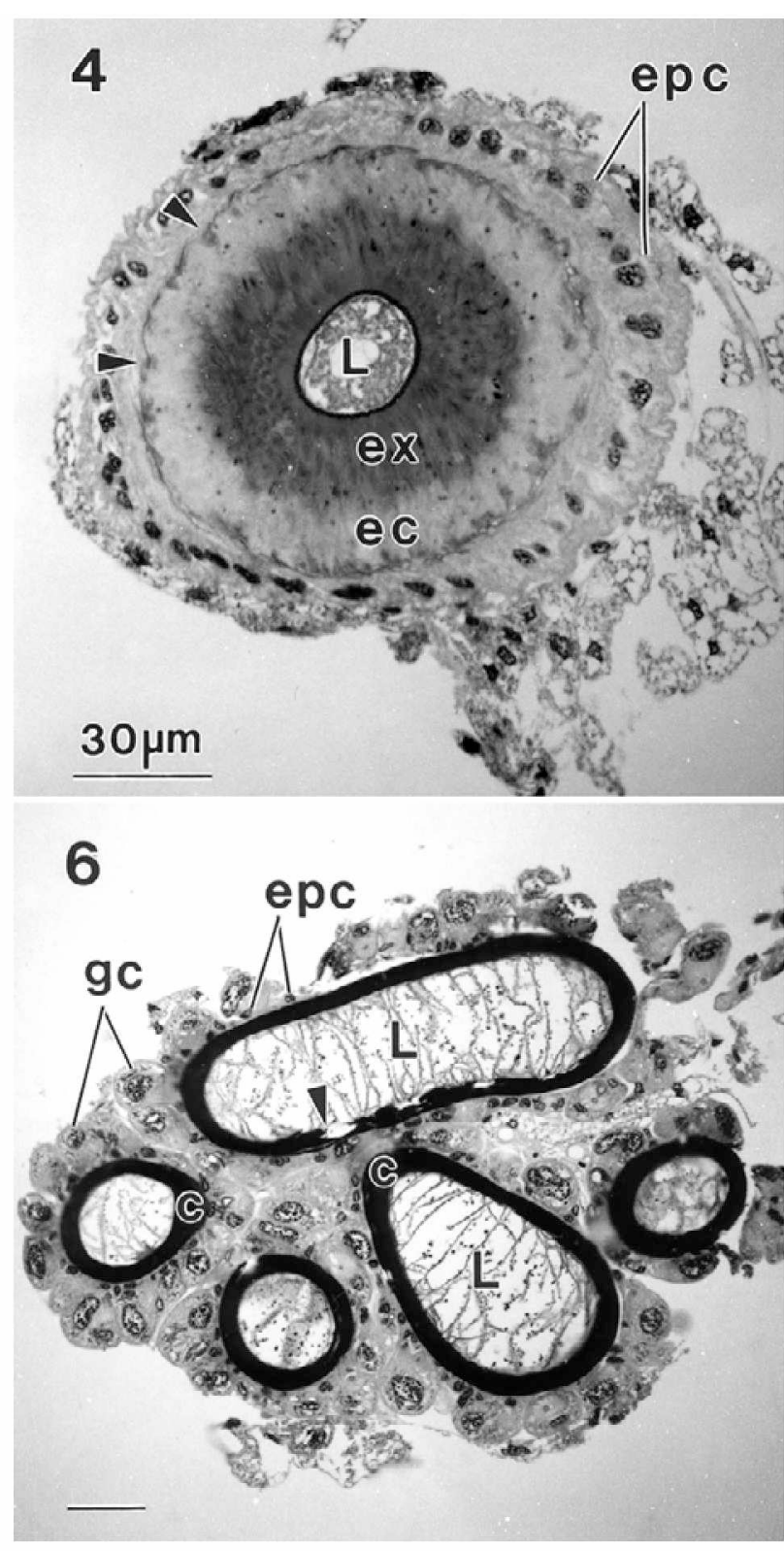

taculum. How this functions is unclear, since we were unable to induce a spermathecal musculature contract. However, the spermathecal musculature is connected to the cuticle via the longitudinally orientated microtubules in the modified epithelial cells (see also Caveney, 1969).

The ability to seal off the ductus receptaculi may allow the females to: (i) present a mechanical barrier to the entry of the processus gonopori and thus insemination, (ii) hold the processus in position for insemination (prolonged copulation, see Sillén-Tullberg, 1981), or (iii) pump sperm from the receptaculum seminis into the bursa copulatrix. Observations on other insects, with severed spermathecal musculature, showed no impairment in spermathecal filling, but a reduced egg fertility (Villavaso, 1975; Rodríguez, 1994) and decreased sperm displacement (Villavaso, 1975).

The length of the ductus receptaculi and the valve in $L$. simulans prolong copulation and reduces the chances of fertilization. Males and females have to remain in copula-

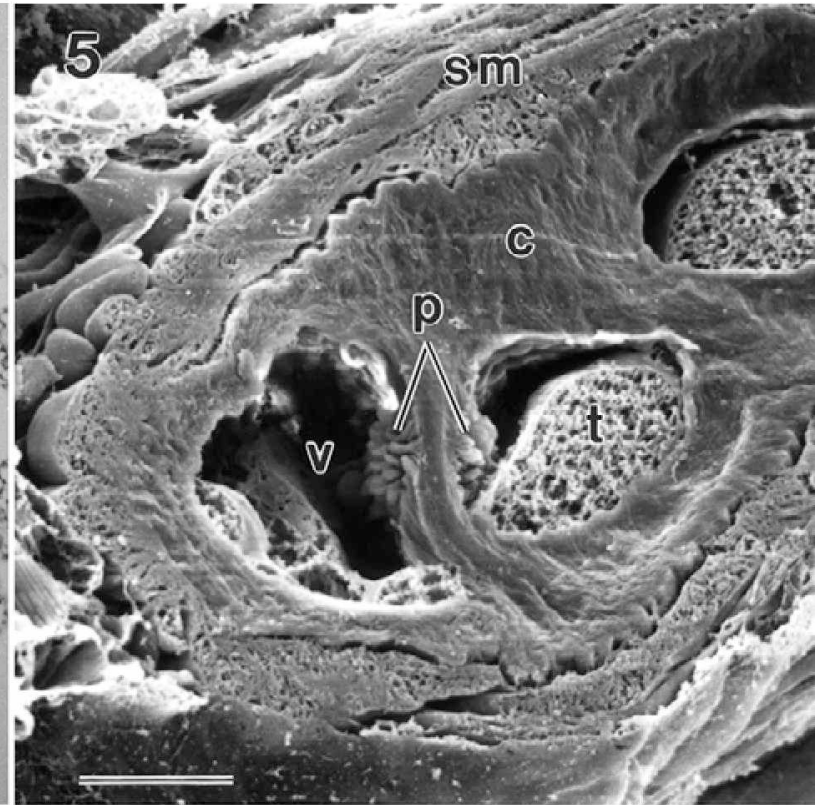

Figs 4-6: Fig. 4. - Light microscope photograph of semithin cross-section of the ductus receptaculi. Note small lumen (L) surrounded by thick layer of endocuticle (ec) and exocuticle (ex) and indentations (arrowheads). epc - epithelial cells; Fig. 5. - SEM photograph of the valve (v) of the ductus receptaculi. Small protrusions (p) are visible on the cuticular wall, which separates the ductus receptaculi from the convoluted tube $(t)$ of the receptaculum seminis. $c$ - cuticle; sm - spermathecal muscle. Scale bar $=30 \mu \mathrm{m}$; Fig. 6. Light microscope photograph of semi-thin section of the receptaculum seminis. Note large glandular cells (gc), small epithelial cells (epc) and large lumen (L) of receptaculum seminis and the lamellated structure of the cuticle (c) with concentric alignment (arrowhead). Scale bar $=30 \mu \mathrm{m}$.

tion at least $30 \mathrm{~min}$ for successful insemination. In spite of this, about one third of the copulations do not result in insemination (Micholitsch, 1997; Tadler, 1999; Tadler et al., 1999). A possible reason for the high rate of failure may be the active closure of the ductus by contraction of the spermathecal musculature. It is likely that females control the entry of the male processus gonopori in this way. Sensory control is also possible, although we did not find any nerves in the area of the valve. The spermathecal muscle in $A$. aegypti also lacks neuromuscular connections (Clements \& Potter, 1967). However, the spermathecal muscles in Periplaneta americana (Gupta \& Smith, 1969) and the muscle fibers of S. granarius, which are restricted to the receptaculum (Tombes \& Roppel, 1972) are under neuroendocrine control.

In conclusion, this study has revealed that the female reproductive organs of the seed bug $L$. simulans are morphologically complex. This contrasts with the commonly held view that insect female genitalia are "uniform and 


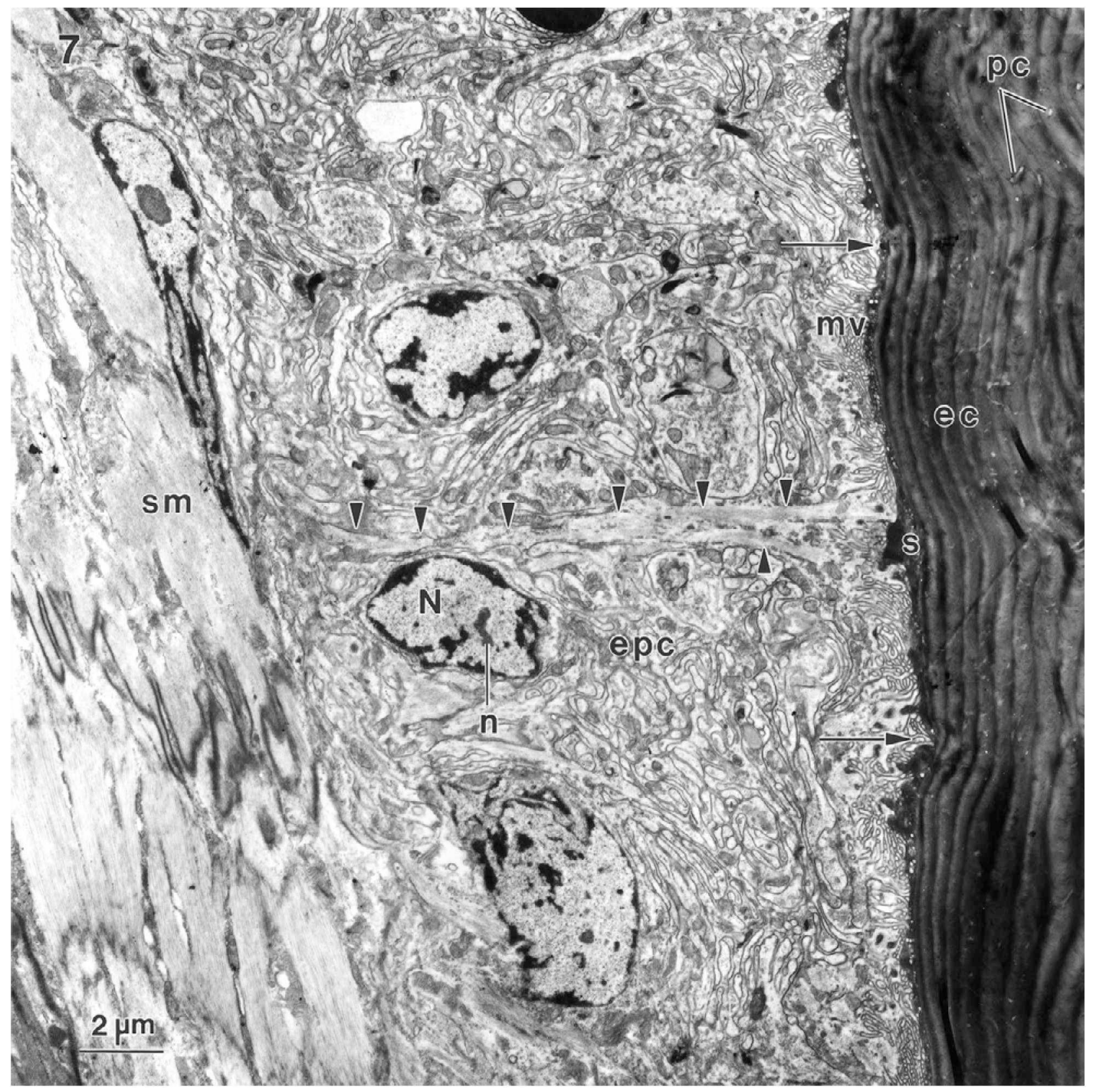

Fig. 7. Electron micrograph of epithelial cells (epc) of the ductus receptaculi in the area of the valve of $L$. simulans. Observe indentations (arrows) and spermathecal muscle (sm) with a microtubular connection (arrowheads) to a swelling (s) of the endocuticle (ec). $\mathrm{mv}$ - microvilli region; $\mathrm{n}$ - nucleolus; $\mathrm{N}$ - nucleus; $\mathrm{pc}$ - pore canals.

sack-like" (for review see Eberhard, 1985). Furthermore, there is an extraordinarily high degree of congruence between the male and female genital structures, and a complicated valve at the distal end of the ductus receptaculi, which plays a role in insemination and fertilization. Females may control the entry of the male processus gonopori by means of the valve and the spermathecal musculature. In this way females may control whether they are inseminated or not based on male genital properties. This is predicted by the cryptic female choice theory of genitalia (Eberhard, 1985, 1996), which was put forward to account for the rapid evolution and high complexity of genitalia in comparison to other morphological structures.
ACKNOWLEDGEMENTS. This work was supported by Austrian Science Foundation (Projekt P 10665-BIO to G. Pass). We thank W. Salvenmoser and D. Reiter for technical help, K. Schatz for photographical assistance and K. Thaler for helpful comments. We are greatful to G. Rieger and three anonymous referees for critical reading earlier versions of the manuscript.

\section{REFERENCES}

Böck P. 1984: Der Semidünnschnitt. J.F. Bergmann, München. BonHAG P.F. \& WICK J.R. 1953: The functional anatomy of the male and female reproductive systems of the milkweed bug, Oncopeltus fasciatus (Dallas) (Heteroptera: Lygaeidae). $J$. Morphol. 93: 177-283. 


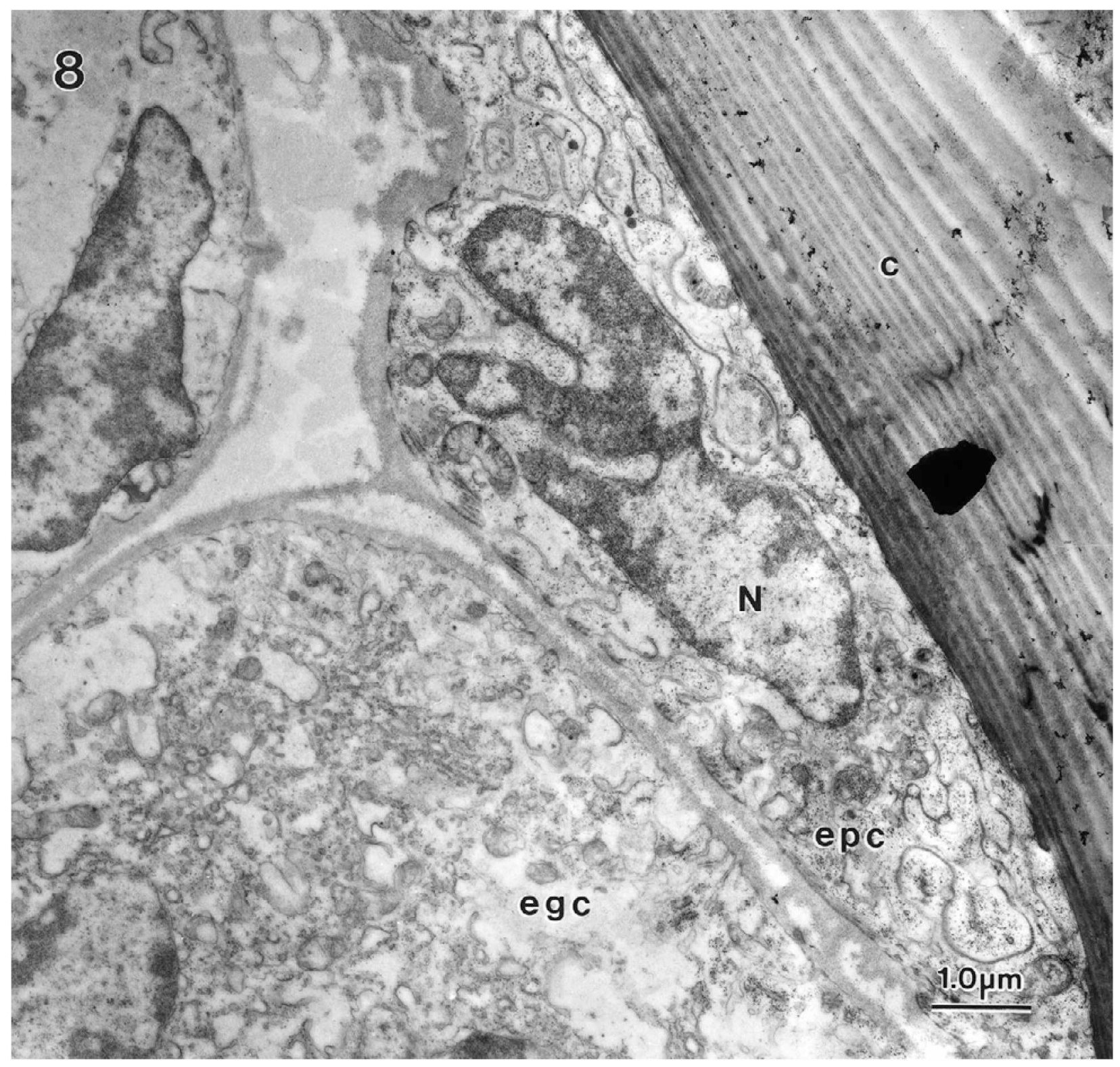

Fig. 8. Electron micrograph of an epithelial cell (epc) and an epidermal gland cell (egc) of the receptaculum seminis of $L$. simulans. $\mathrm{c}$ - cuticle; $\mathrm{N}$ - nucleus.

Clements A.N. \& Potter S.A. 1967: The fine structure of the spermathecae and their ducts in the mosquito Aedes aegypti. J. Insect Physiol. 13: 1825-1836.

CAVENEY S. 1969: Muscle attachment related to cuticle architecture in Apterygota. J. Cell Sci. 4: 541-559.

Dallai R., Del Bene G. \& Lupetti P. 1996: Fine structure of spermatheca and accessory gland of Franklinella occidentalis (Pergande) (Thysanoptera: Thripidae). Int. J. Insect Morphol. Embryol. 3: $317-330$

DeCKeRT J. 1985: Über Lygaeus simulans spec. nov. und L. equestris (Linnaeus, 1758), zwei nahe verwandte paläarktische Lygaeinae (Heteroptera, Lygaeidae). Mitt. Zool. Mus. Berl. 61: 273-278.

EBerhard W.G. 1985: Sexual Selection and Animal Genitalia. Harvard University Press, Cambridge, Massachusetts, and London, England.

Eberhard W.G. 1996: Female Control: Sexual Selection by Cryptic Female Choice. Princeton University Press.
EквLом T. 1926: Morphological and biological studies of the Swedish families of Hemiptera-Heteroptera. Zool. Bidr. Upps. 10: $31-180$

GuptA B.L. \& SMith D.S. 1969: Fine structural organization of the spermatheca in the cockroach, Periplaneta americana. Tissue Cell 1: 295-324.

KaHLow E. 1962: Untersuchungen zur Morphologie des männlichen Kopulationsapparates der Rhynchoten: Lygaeus equestris L. und Philaenus spumaenus L. Beitr. Entomol. 12: $555-581$.

LudwIG W. 1926: Untersuchungen über den Copulationsapparat der Baumwanzen. Z. Morph. Oekol. Tiere (Berlin) 5: 291-380.

Norrot C. \& QUENNEDEY A. 1974: Fine structure of insect epidermal glands. Anmu. Rev. Entomol. 19: 61-80.

MicholrtsCH T. 1997: Insemination and Fertilization in Lygaeus simulans (Heteroptera: Lygaeidae): Are there Indications for "Cryptic Female Choice"? Magister thesis, Universität Wien. 
Pendergrast J.G. 1957: Studies of the reproductive organs of the Heteroptera with a consideration of their bearing on classification. Trans. R. Entomol. Soc. Lond. 109: 1-63.

RICHARDSON K.C., JARRET L. \& FINKE E.H. 1960: Embedding in epoxy resins for ultrathin sectioning in electron microscopy. Stain. Technol. 35: 313-325.

Rieger R.M., Salvenmoser W., Legniti A. \& Tyler S. 1994 Phalloidin-rhodamin preparations of Macrostomum hystricinum marinum (Plathelminthes): morphology and postembryonic development of the musculature. Zoomorphology 114: 133-147.

RoDríguez V. 1994: Function of the spermathecal muscle in Chelymorpha alterans Boheman (Coleoptera: Chrysomelidae: Cassidinae). Physiol. Entomol. 19: 198-202.

RomeIs B. 1968: Mikroskopische Technik. R. Oldenburg, München, Wien.

Sillén-Tullberg B. 1981: Prolonged copulation: a male "postcopulatory" strategy in a promiscous species, Lygaeus equestris (Heteroptera: Lygaeidae). Behav. Ecol. Sociobiol. 9: 283-289.

SмITH D.S. 1968: Insect Cells, Their Structure and Function Oliver and Boyd, Edinburgh.

SNODGRASS R.E. 1935: Principles of Insect Morphology. McGraw-Hill, New York and London
SPURR A.R. 1969: A low-viscosity epoxy resin embedding medium for electron microscopy. J. Ultrastruct. Res. 26: $31-43$.

Stefanini M., De Martino C. \& Zayboni L. 1967: Fixation of ejaculated spermatozoa for electron microscopy. Nature (London) 216: 173-175.

TADLER A. 1999: Selection of a conspicuous male genitalic trait in the seedbug Lygaeus simulans. Proc. R. Soc. Lond. 266: $1773-1777$.

Tadler A., NemeschKal H.L. \& Pass G. 1999: Selection of male traits during and after copulation in the seedbug Lygaeus simulans Heteroptera, Lygaeidae. Biol. J. Linn. Soc. 68: 471-483.

TOMBES A.S. \& ROPPEL R.M. 1972: Ultrastructure of the spermatheca of the granary weevil, Sitophilus granarius (L.) (Coleoptera: Curculionidae). Int. J. Morphol. Embryol. 1: 141-152.

VILLAVASO E. 1975: Functions of the spermathecal muscle of the boll weevil, Anthonomus grandis. J. Insect Physiol. 21: 1275-1278.

Wheeler D.E. \& Krutsch P.H. 1994: Ultrastructure of the spermatheca and its associated gland in the ant Crematogaster opuntiae (Hymenoptera, Formicidae). Zoomorphology 114: 203-212.

Received November 23, 1999; accepted March 28, 2000 